\title{
PAUL, THE TRINITY, AND CONTEMPORARY TRINITARIAN DEBATES
}

\author{
CHRIS TILLING \\ St Mellitus College \\ London, England
}

"The twentieth century" so write Christophe Chalamet and Marc Vial, "can be seen as the century of a rediscovery of trinitarian thought". ${ }^{1}$ As they point out, this had led to a number of controversies, including the definition of "personhood" and the relationship between the "economic" and the "immanent" Trinity. But perhaps most importantly, the latest debates concern the claim that this rediscovery presents nothing other than "thoroughgoing departures from the older tradition, rather than revivals of it". This, at least, is the judgment of Stephen Holmes. ${ }^{2}$ It is a damning assessment of so-called "social" or "relational" models of the Trinity, which speak of divine ontology in terms of relationality, movement, dance etc., i.e., those that resist "static" notions of Being parsed in terms of a doctrine of divine simplicity. Hence, the recent Counterpoints book, Two Views on the Doctrine of the Trinity, which gave space for representatives in this debate to discuss matters head on, is an important service to the wider ecclesial and theological community. ${ }^{3}$ In this volume, Paul Fiddes presents a defence of the "relational" model of the Trinity, precisely that which Holmes claims is an illegitimate development away from the tradition. ${ }^{4}$ In the following I will reflect on a number of concerns in this debate as they emerge from the perspective of the writings of the apostle Paul. I begin by discussing Paul and the Trinity in dialogue with Wesley Hill's recent monograph of the same name. In light of this, I present a few reflections on this contemporary theological debate, largely by critiquing aspects of Holmes' thesis from the perspective of Pauline exegesis.

\section{FROM PAUL AND THE TRINITY TO PAUL'S TRINITY}

I know of only one modern monograph dedicated specifically to Paul's writings and the Trinity, namely Wesley Hill's important and lucid recent work. ${ }^{5}$ It will thus be necessary to engage with his claims in the following. I do this as a launch pad for engaging Paul's letters more inductively, precisely because in so doing, I will argue, light will be shed on the debates noted above.

\footnotetext{
${ }^{1}$ Christophe Chalamet and Marc Vial, "Introduction," in Recent Developments in Trinitarian Theology: An International Symposium, ed. Christophe Chalamet and Marc Vial (Minneapolis: Fortress Press, 2014), 3.

2. Stephen R. Holmes, The Holy Trinity: Understanding God's Life, Christian Doctrines in Historical Perspective (Milton Keynes: Paternoster, 2012), xvi.

3. Jason S. Sexton, ed., Stephen R. Holmes, et al., Two Views on the Doctrine of the Trinity, Counterpoints: Bible \& Theology (Grand Rapids, Mich.: Zondervan, 2014).

4. "[T] he doctrine of the Trinity that we have witnessed in recent decades in fact misunderstands and distorts the traditional doctrine so badly that it is unrecognizable" (Holmes, The Holy Trinity, xv).

5. Wesley Hill, Paul and the Trinity: Persons, Relations, and the Pauline Letters (Grand Rapids, Mich.: Eerdmans, 2015).
} 
Hill's monograph claims that Pauline scholarship has become locked in an anti-Trinitarian agenda. Indeed, his concern is difficult to deny. Any suggestion that Paul could be fruitfully understood in Trinitarian categories is likely to be seen as problematic anachronism. So the spirit of the academy of biblical studies might say "Thrust such categories onto Paul and one will inevitably do violence to the interpretative task. Such attempts are worthy for church Bible study groups, perhaps, but let's keep them out of the academy"! Hence, so argues Hill, modern scholarship ignores the Trinity and concerns itself, instead, with the question of Christology, particularly to what extent that Christology is fully divine or not. Further, to answer this in a non-Trinitarian manner, a new term, "monotheism”, has been inserted into the debate. Christology is then measured on a vertical scale: how high (or low) can one place Paul's Christology in terms of this (Jewish) monotheistic given?

Such is the lot of biblical scholars reading Paul, Hill argues. Does he have evidence? Plenty! So some scholars, as Hill notes, suggest that Paul's Christ cannot be allowed full divinity precisely because of the "restraining factor" of Jewish monotheism. 6 Others are confident that Paul's Christ is indeed divine, and in this camp he notes the contributions of Hurtado and Bauckham. ${ }^{7}$ The problem is that both of these groups of scholars have adopted a rather inadequate interpretative paradigm, one which is too concerned with "vertical" metaphors alone (how "high" Paul's Christology is or not). So he asserts (not entirely fairly) that "all" of these interpreters "share a concern to distance their reconstructions of New Testament christology from later Trinitarian theology". ${ }^{8}$ Instead, and this is Hill's constructive claim, the Trinitarian categories of "relations" offers a more fruitful and exegetically helpful perspective.

To make this claim, Hill draws on suggestive hints in the scholarship of Keck, Rowe and Watson, ${ }^{9}$ all of which approve of a relational approach to Paul's language. But this, Hill thinks, is the first monograph

6. Among others, Hill notes James F. McGrath, The Only True God: Early Christian Monotheism in Its Jewish Context (Urbana: University of Illinois Press, 2009), the various works of Dunn (e.g., James D.G. Dunn, Did the First Christians Worship Jesus?: The New Testament Evidence [London: SPCK, 2010]), and Maurice Casey, "Monotheism, Worship and Christological Developments in the Pauline Churches," in The Jewish Roots of Christological Monotheism, eds C.C. Newman, J.R. Davila, and G.S. Lewis (Leiden: Brill, 1999), 214-33.

7. See, e.g., Larry W. Hurtado, Lord Jesus Christ: Devotion to Jesus in Earliest Christianity (Grand Rapids: Eerdmans, 2003), and Richard J. Bauckham, Jesus and the God of Israel (Milton Keynes: Paternoster, 2008).

8. Hill, Paul and the Trinity, 18. He is also not fair to accuse these examplars of scholarship as concerned to discuss Christology as something "discussable, in principle, in relative isolation" (23). None of them pretend to be able to say something about Christology without keeping God-language in mind. This is especially true for Bauckham, who understands the contours of his Christology precisely in terms of faith in God, and vice-versa (see Richard J. Bauckham, God Crucified: Monotheism and Christology in the New Testament [Carlisle: Paternoster, 1998]). It is also not the case that an analysis of Christology on a vertical axis necessarily leads one to sideline relational matters, namely the interrelation of Father, Son and Spirit (as I understand him to argue in his first chapter). I respond by claiming that it depends entirely how the question is answered and how inductively one treats the interrelation of themes in Paul's texts. For my own part, and as we shall see again in what follows, I make claims about divine Christology in Paul (in ways he may align with Bauckham and Hurtado) precisely by making Paul's God and Spirit language vital to the task.

9. See, e.g., L.E. Keck, "Toward the Renewal of New Testament Christology," NTS 32 (1986): 362-77, Francis Watson, "The Triune Divine Identity: Reflections on Pauline God-Language, in Disagreement with J.D.G. Dunn," JSNT 80 (2000): 99-124, C. Kavin Rowe, "Biblical Pressure and Trinitarian Hermeneutics," ProEccl11, no. 3 (2002): 295-312. 
of its kind. Hill will understand Christology not in isolation, but in relation to God and Spirit language, all as mutually interpreting terms. This is not to say that he seeks to find the Trinity in Paul. He rather adopts Trinitarian categories to shed light on Paul's letters. This entails showing that "each [divine] person is only identifiable by means of reference to the others". ${ }^{10}$ The contours of this project are not, therefore, idle theological anachronism. He presents what he considers to be "self-consciously historical readings" of Paul,11 in such a way that (laudably) brings theology back into conversation with such exegesis.

Before he begins his exegetical work, Hill overviews the way relationality has informed Trinitarian discourse, both in "classical theism" on the one hand, climaxing in Aquinas' "subsistent relations", and in modern proposals on the other, which emphasise in very different ways more "personalist" ontologies (Zizioulas, Moltmann, Jenson etc.). ${ }^{12}$ It is rather odd that Hill only makes extended use of classical Trinitarian discourse in his exegetical work, ${ }^{13}$ which conceives of "relation" in restricted terms. Classical Trinitarian language uses the term as something "primarily logical, not personal", as Holmes summarises. ${ }^{14}$ The single and limited exception to understanding God in strictly simple terms, is to understand the names "Father", "Son" and "Spirit" as relations of origin, so the argument goes. ${ }^{15}$ And this is the classical Trinitarian heritage which Hill seems to endorse (his second supervisor was Lewis Ayres!) over against what has unhappily been called "social Trinitarianism". ${ }^{16}$ But although Hill does speak of Paul's "Father" and "Son" in terms of origin, this only happens a couple of times, ${ }^{17}$ and not at all in terms of the Spirit. ${ }^{18}$ Simply put, Hill wants to say more in his exegesis about the relations of Father, Son and Spirit than can be reduced to matters of origin. ${ }^{19}$ (The strategy of "redoublement" does, however, draw much energy from classical Trinitarian distinctions. He successfully shows this in chapters three and four.)

This leads, in chapter one, to an analysis of texts which understand God in relation to Jesus (Rom. 4:24; 8:11). He chooses these texts because he thinks that they involve "identity descriptions" of God in relation to Jesus. So, for example, God is identified, described, "picked out from the crowd" as "the one who raised Jesus our Lord from the dead". ${ }^{20}$ This leads Hill to reject the use of the term "monotheism", as

10. Hill, Paul and the Trinity, 44.

11. Ibid., 45.

12. As noted by Hill. See, e.g., Robert W. Jenson, Systematic Theology. Volume 1. The Trimne God (Oxford: OUP, 1997), Jürgen Moltmann, The Trinity and the Kingdom: The Doctrine of God (Minneapolis: Fortress, 1981), J.D. Zizioulas, Being as Communion: Studies in Personhood and the Church (Crestwood, NY: St. Vladimir's Seminary Press, 1985), etc.

13. See his revealing comment in Hill, Paul and the Trinity, 103-4 n.89.

14. Stephen R. Holmes, "Classical Trinity: Evangelical Perspective," in Two Viens on the Doctrine of the Trinity, ed. Jason S. Sexton (Grand Rapids, Mich.: ZOndervan, 2014), 38.

15. On all of this, see Holmes, "Classical," 37; Holmes, The Holy Trinity, 199-200.

16. See his reference to Bruce Marshall's "penetrating critique of the twentieth-century trinitarian 'renewal"' (Hill, Paul and the Trinity, 36 n.124).

17. Hill, Paul and the Trinity, 77, 111.

18. As far as I could see.

19. Here I would note, as examples, his exegesis of 1 Cor. 15:24-28, which speaks of "particular actors and agents" (130). Even more telling, see his analysis of Paul's language relating to the Spirit and his role in resurrection (135-163). On all of this, see now the strong emphasis on personal language in Matthew W. Bates, The Birth of the Trinity: Jesus, God, and Spirit in New Testament and Early Christian Interpretations of the Old Testament (Oxford: OUP, 2015). His personcentred exegetical procedure portrays Father, Son, and Spirit not simply in terms of procession of origin, but in terms of their "relentless affection and concern for one another" (7).

20. See Hill, Paul and the Trinity, 54. 
deployed by the likes of Dunn, as the "larger explanatory category" in light of which Christology is assessed. ${ }^{21}$ Rather, for Paul "there is no monotheism without christology". ${ }^{22}$

In chapters three and four, Hill examines passages that portray Jesus in relation to God. Here he examines Philippians 2:6-11, 1 Corinthians 8:6 and 15:24-28. These texts obviously require that Hill attend to the asymmetry in the relation between God and Jesus. God sends and himself isn't sent. Jesus is sent and doesn't send (the Father). These "subordination" texts (or subordination elements within these texts, as with Phil. 2:6-11), often seen as problematic for "high Christology" proponents, are tackled by Hill in a very different way. Using the Trinitarian strategy of "redoublement" (as termed by Ghislain Lafont), Hill takes seriously passages in Paul that subordinate the Son to the Father. These are not texts to be apologetically explained away, but are to be read in terms of the (Trinitarian) distinction between Father and Son. At least this is the first stage of reading. Given that Paul also uses language that implies the full divinity of Jesus, something Hill ties particularly to the title xügros, ${ }^{23}$ there is also a second reading, one which sees Christ as fully divine. So we end up with Christ as distinct from the Father, but fully divine. Orthodox Trinitarian categories here facilitate a better appreciation of the full scope of Pauline language, without having to minimise or demote anything.

The upshot is that, for Paul: "God and Jesus are identified with one another at the level of the shared divine name xúgıs and yet they are also irreducibly distinguished from one another in that God is $\pi \alpha \tau \dot{\eta} \varrho$ and Jesus Christ is the raised, exalted one." 24 In chapter five, Hill turns attention to the Spirit in relation to God and Jesus. Taking his cue from Rowe's excellent essay, he analyses "the relational determination of the Spirit's identity". ${ }^{25}$ Hill argues that the Spirit "derives 'his' character from God and Jesus". ${ }^{6}$ In 1 Corinthians 12:3 and Galatians 4:4-6, Hill understands Paul to say that the Spirit mediates the presence of the risen Lord Jesus. In this way the Spirit is identified. Via analysis of Romans 1:3-4 and 8:9-11, Hill further maintains that the identity of God and Jesus in the economy of salvation is only specifiable by the Spirit. The sonship of Jesus, and so the fatherhood of God, is "constituted in and through the Spirit's role in raising Jesus". ${ }^{27}$ I would quibble with some of his exegetical judgments at this point as I remain convinced by Fatehi's reading of 2 Corinthians 3:17. Plus, I think some of his arguments claim more than the texts allow. ${ }^{28}$ But either way, there is much to enjoy in this chapter, and Hill proceeds into a justified broadside against talk of Pauline "binitarianism". Such language is "drastically misleading", 29 a conclusion with which we strongly agree (as we shall see below).

21. Hill, Paul and the Trinity, 71.

22. Ibid., 72.

23. See Hill, Paul and the Trinity, 112.

24. Hill, Paul and the Trinity, 133.

25. C. Kavin Rowe, "The Trinity in the Letters of St. Paul and Hebrews," in The Oxford Handbook of the Trinity, ed. Matthew Levering and Gilles Emery O.P. (Oxford: OUP, 2011), 50.

26. Hill, Paul and the Trinity, 137.

27. Ibid., 138.

28. Mehrdad Fatehi, The Spirit's Relation to the Risen Lord in Paul: An Examination of Its Christological Implications (Tübingen: Mohr Siebeck, 2000), 289-308.

29. Hill, Paul and the Trinity, 165. 
In all of this, Hill hopes that his approach will shed fresh exegetical light on Paul. Arguably, Hill has succeeded in showing that certain Trinitarian categories are entirely appropriate for a better understanding of Paul's letters, and the nature of Paul's rhetoric concerning God, the Spirit and Jesus. He rightly notes that all such language overlaps and that to analyse, for example, Christology in isolation from pneumatology, would be to distort Paul. He is right that Paul's God-language is profoundly shaped by Jesus Christ. In all of this, Hill's monograph is an important contribution to contemporary Pauline studies.

I also found his deployment of "redoublement" helpful, albeit with one caveat. Namely, although he thinks that his strategy moves beyond the Pauline scholarly puzzlement at dialectic, where Pauline scholars, we are told, make "no attempt ... to press for a deeper coherence", ${ }^{30} \mathrm{I}$ think he overestimates the explanatory power of the solution he proposes. After all, it is not that redoublement solves the issues conceptually. The paradox is transferred into a particular and well-worked out idiom (involving language such as prosopon, persona, bypostasis and subsistentia on the one hand, and ousia, substantia, and natura on the other), but classical Trinitarian theology, at least, remained humble about its precision at this point. So Augustine stated: "[T]he formula three persons has been coined, not in order to give complete explanation by means of it, but in order that we might not be obliged to remain silent." 31 As another example, note that for Gregory of Nazianzus, too, an understanding of the unity of God and the distinctions within God were not metaphysical solutions or developed doctrines. In a sense, the matter remained mystery, known only to those "purified souls to whom the Trinity may make revelation" (Or. 23.11).32

What is more, given that Hill describes his task as "self-consciously historical" such that at "no point will a trinitarian conclusion be allowed to 'trump' what Paul's texts may be plausibly shown to have communicated within his own context", 33 some explanation remains outstanding. The question thus remains, How did Paulmanage to hold this paradox given that he did not operate with the later philosophical distinctions involved in the language noted above? I agree that Trinitarian theology helps us to comprehend these texts together, as a retrospective strategy. But if no "trumping" is to happen, other routes may help as partial explanations. Precisely this is a matter I explored in an earlier publication which allowed me to affirm the presence of subordination texts without needing to explain them away. ${ }^{34}$ And this was a proposal made more consciously on Paul's terms; it was "historical" exegesis, but in ways that correspond, I hope naturally and responsibly, with later doctrinal formulations.

This is to suggest that historical concerns involved in critical exegesis may not have been allowed enough breathing room in Hill's analysis. This is suggested also by Hill's reasonably sparse engagement with the variety of relevant and important second Temple Jewish literature. This is seen most poignantly in what

30. Ibid., 122.

31. De Trinitate 5.9.10. See also his comments relating both to Paul and our necessary posture of humility in 1.5.8.

32. On this, see Christopher A. Beeley, Gregory of Narianzus on the Trinity and the Knowledge of God: In Your Light We Shall See Light, Oxford Studies in Historical Theology (Oxford: OUP, 2008), 223.

33. Hill, Paul and the Trinity, 45.

34. See Chris Tilling, Paul's Divine Christology (Grand Rapids, Mich.: Eerdmans, 2015²), 254-57. In a nutshell, I exploit appreciation for Paul's relational epistemology. This makes room for precisely such paradox in Paul without it becoming an incoherence Paul would recognise as such. This resonates, then, with at least the posture of Gregory of Nazianzus, noted above. 
Hill completely ignores. So he (I think rightly) argues that Christ's distinction from God as Father does not mean the full divinity of Christ is jeopardised. But as Hill knows, precisely this distinction has been exploited by those who use the category of second Temple Jewish agency figures to understand Christ in Pauline terms. In many Jewish texts an exalted intermediary agent of some sort of heavenly glory reigns alongside God, bears God's name, receives worship and so on. Likewise, in this Jewish milieu, out of which Paul writes, Jesus Christ is in many ways much like one of these agents alongside God. A legitimate historical question thus remains: why would a Trinitarian conceptuality be preferred over this Jewish language of divine agency? Hill does not answer this. Or why, as a historically plausible proposal, should one accept that certain isolated passages be deemed "identity descriptions" (such as Rom. 4:24)? Hill needs to do more work to demonstrate that these exegetical decisions are not arbitrary. Other scholars could equally make appeal to different, potentially theologically difficult, passages as "identity descriptors", such as those which can be read to state that God isn't simply Christ's Father, but also his God. ${ }^{35}$ Precisely these questions are explored by those exegetes from whom Hill wishes to distance himself (Hurtado, Bauckham, Dunn etc.). In other words, Hill needs to be careful that he does not allow his (appropriate) hermeneutical lens to diminish the vitality of very real and important historical concerns.

What is more, I was a little concerned to read the argument proffered in his second chapter, which suggests that deploying Trinitarian categories refutes those who think "the primary question [is] how to understand the exalted status of Jesus within a continuing affirmation of Jewish monotheism". ${ }^{36}$ Instead, so his argument runs, better to focus on how God-language in Paul is indeed shaped by Christ. I accept this point to a degree. ${ }^{37} \mathrm{~A}$ retrospective hermeneutic, as exemplified particularly in apocalyptic readings of Paul, is the most promising both exegetically and theologically, in my view. ${ }^{38}$ However, there is a sense in which the givenness of Jewish monotheism cannot be so neatly brushed aside, as it effectively is in Hill's analysis. Its explication is a necessary (though of course not sufficient) historical task for understanding Paul. Imagine how different things would look if Paul's Jewish background was polytheistic! Understanding the role of the divine actors in Paul requires some accounting of his milieu. More than that, by keeping the general contours of Paul's God-language in mind, and our understanding of this in hermeneutical conversation with wider themes in Jewish monotheism, crucial light is shed on the depth and colour of Paul's language about God, Christ and the Spirit, a point to which we will return later. The concerns relating to epistemology in the "apocalyptic" school can be honoured in terms of a more complex, oscillating portrayal of hermeneutical

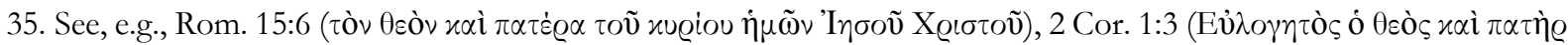

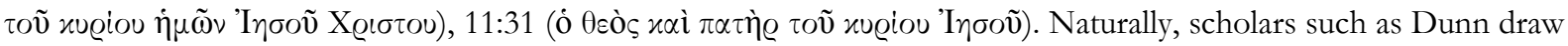
attention to these passages (e.g., James D.G. Dunn, The Theology of Paul the Apostle [Grand Rapids: Eerdmans, 1998], 254).

36. Hill, Paul and the Trinity, 18-19.

37. And to the degree I do so, I accept it happily. This is one reason why I published Chris Tilling, ed., Beyond Old and New Perspectives on Paul: Reflections on the Work of Douglas Campbell (Eugene, Or.: Cascade, 2014).

38. See the seminal essay by J. Louis Martyn, "Epistemology at the Turn of the Ages: 2 Corinthians 5.16," in Theological Issues in the Letters of Paul (Edinburgh: T\&T Clark, 1997), 89-110. 
realities. ${ }^{39}$ All of this is to suggest that there are more vigorous ways to bring historical exegesis and theology together. Indeed, and to put things as sharply as possible. Hill presents an analysis of Paul by means of trinitarian categories. And he does shed a good deal of light of matters. However, we are a long way from understanding Paul's trinitarianism, a matter to which we will attend below.

A final bone of contention is to suggest that by attending to Trinitarian relations in such straightforward terms (the relations between Son, Father and Spirit), there is a danger that the nature of Paul's own language will be sidelined, ignored or underestimated. Of course, Hill needed to decide on a particular focus, draw lines around his research to stop it becoming unwieldy. He needed to make judgment calls and focus on some passages, not others, certain themes and not everything at once. But I submit that to focus on just the relations between the divine actors is to potentially obscure matters when speaking about Paul and the Trinity. Summarising the import of Trinitarian theology, Hill states: "each [divine] person is only identifiable by means of reference to the others". ${ }^{40}$ There is a sense in which this may be formally true, but for Paul, each divine person is identifiable, known, spoken about and confessed, also in terms of that Spirit animated and graced human relationship with God and Christ. Exegetical issues will otherwise be overlooked.

Indeed, these are also the dynamics inherent in the classical Trinitarianism Hill makes recourse to with such skill. As examples, I can draw attention to the foregrounding of a particular account of epistemology in recent expositions of Gregory of Nazianzus and Augustine. Of the former, Beeley writes:

In Gregory's view, Christian theology involves and represent a dynamic, lived relationship between God and the theologian, and so it begins not with abstract information about God-as if this could ever be acquired neutrally_-but with the transformation of the theologian within the horizon of God's presence and activity in the world, as it is recognized and celebrated in the life of the church. It is a common refrain in Gregory's work that spiritual progress and right belief unavoidably go together ... it is impossible to separate Gregory's doctrine of God from his doctrine of the means by which God is known. ${ }^{41}$

Interestingly, Gregory derives some of these commitments from his reading of Paul.42 As Beeley expounds at length, for Gregory the knowledge of the Trinitarian God does not come about by means of abstract doctrinal comprehension. It is about participation, "a form of knowledge that comes by faith and service to God". 43

In De Trinitate, Augustine explains how theology approaches its “object”, how humans may speak about God as Trinity. Luigi Gioia summarises a key strand in Augustine’s answer:

God does not make himself known in the Old and in the New Testament primarily through the communication of the set of propositional truths about himself_-even though, of course, these are

39. Chris Tilling, "Campbell's Apocalyptic Gospel and Pauline Athanasianism," in Beyond Old and New Perspectives on Paul: Reflections on the Work of Douglas Campbell, ed. Chris Tilling (Eugene, Or.: Cascade, 2014), 69-72.

40. Hill, Paul and the Trinity, 44.

41. Beeley, Gregory of Nazianzus, 64.

42. See Beeley, Gregory of Nazianzus, 69.

43. Beeley, Gregory of Nazianzus, 229. 
part of the process of revelation-but through the creation of the covenant, the relation with his creatures which involves all their existence, all their beings ... Thus, knowledge of God and (covenantal) relation with him are coextensive and mutually conditioning. ${ }^{44}$

Similarly, I submit that to more adequately portray Paul's rich proto-Trinitarianism ${ }^{45}$ is to grasp wider themes coloured by the relation between Christ and his church, ${ }^{46}$ between God and the members of the body of Christ, and these as animated and actualised by the Spirit.

The following is a defence of this claim, but it is written also with an eye on the debates outlined at the beginning. This is to say that developing my point here will simultaneously address the initial controversy outlined above relating to different visions of Trinitarian ontology. It does this by building on Hill's case, avoiding some of the potential weaknesses on the way. In particular, I wish to work more thoroughly with the scope of language in Paul's letters, as well as show greater respect for the historical task. This will allow great precision when discussing Paul in Trinitarian terms. For just as Hill is correct to claim that a Trinitarian grammar, one which he carefully defines, sheds light on Paul's God, Christ and Spirit language, so too is it the case that God the Father and the Son, both by the Spirit, are known in such a way that irreducibly involves human relation with God and Jesus by the Spirit. Otherwise put, to know this God is to be in relationship with God. And this, we shall see, is of no small significance.

$-\int 1.2 .-$

Bearing these observations in mind, in the following I propose nine theses as crucial backbone for an alternative way of engaging with the question of Paul and the Trinity. This section will be shorter than it deserves as I have already detailed the main points to be here summarised in numerous publications. ${ }^{47} \mathrm{It}$ also needs to be stressed that the first three theses are formally provisional as depictions of second temple texts, for my point is to elucidate Paul's theology.

44. Luigi Gioia OSB, The Theological Epistemology of Augustine's De Trinitate, Oxford Theological Monographs (Oxford: OUP, 2008), 4. For different emphases, see also Lewis Ayres, Augustine and the Trinity (Cambridge: CUP, 2010), 14273.

45. I use this word with the prefix "proto" to acknowledge that Paul's theology is both worthy of the description "Trinitarian", but also that it is (obviously) not developed in terms of later, creedal formulations which parsed divine unity and distinctions with language-use alien to Paul. See also Gordon D. Fee, Pauline Christology: An ExegeticalTheological Study (Peabody: Hendrickson, 2007), 63 n.98.

46. Of course, to translate Paul's غ̇ $x \varkappa \lambda \eta \sigma i \alpha$ as "church" runs into problems. Needless to say, I do not wish to connote specific later ecclesial structures or suggest Paul is talking about a building. If my stubbornness in using the word "church" causes the reader to stumble, I suggest "Christ-assembly" as a good alternative (I credit Charles Puskas for this suggestion).

47. Tilling, Paul's Divine Christology, especially 63-72, 76-90, 197-206, 228-40; Chris Tilling, "Ephesians and Christology," in Christ, Spirit and the Church: Essays in Honour of Max Turner, ed. Volker Rabens, Howard I. Marshall, and Cornelis Bennema (Grand Rapids, Mich.: Eerdmans, 2011), 177-97; Chris Tilling, "Misreading Paul's Christology: Problems with Ehrmans' Exegesis," in How God Became Jesus: The Real Origins of Belief in Jesus' Divine Nature. A Response to Bart Ehrman, ed. Michael F. Bird (Grand Rapids, Mich.: Zondervan, 2014), 134-50. 
(1) The first thesis is that in second Temple Judaism, God-language was expressed in terms of a broadly consistent and identifiable pattern. As Bauckham has detailed, God is described in terms of his ${ }^{48}$ relationship with all creation, such that God is spoken of as eternal and sovereign..$^{49}$ But this is not always obvious, and certain figures seem to blur these boundaries (e.g., Philo's logos) So more important, because it dominates second Temple material, is the way God is characterised as in relation with bumanity, and particularly Israel of course. In this capacity, the usual themes that speak of this relation can be broken down in the following way:

- Communication. God is the one who speaks and addresses his people. God is, likewise, the recipient of human prayers. This is to say that there are channels of communication to and fro, between God and people.

- Presence and activity. God is active in the world in various ways.

- Spirit. This activity is the activity of the Spirit. It follows that all Spirit-language in second temple Judaism is God-language and speaks of "God's activity as he relates himself to his world, his creation, his people". ${ }^{50}$

- "Absence". There remains, however, a sense in which God is "absent". The ambiguity involved in speaking of God as "not present" is inevitable. But it remains the case that God's absence can be expressed either existentially, or with spatial metaphors. ${ }^{51}$

- Character. God is characterised in typical ways, albeit with different emphases. God is faithful, just, wrathful, loving, etc.

- Devotion. The human response (and sometimes not just human!) is described with a variety of devotion-orientated language, a theme which encompasses the cult, but also necessary moves beyond the cult into the whole of life. ${ }^{52}$ This devotion is typically expressed in ways that emphasise both complete and fervent commitment, and is contrasted with a familiar gamut of language (sin, idolatry, deception, and so on).

(2) It is to be noted that these broad brushstroke categories are consistently deployed in speaking of Israel's God. This corresponds with my second thesis, namely, the uncontroversial observation that within second temple Judaism, faith in God was understood in relational terms. ${ }^{53}$ This is to say that God was not simply an object

48. I am sympathetic to concerns relating to the use of gender specific language, when speaking of God, but I will adopt the male pronoun in the following. On this, see now Paul R. Hinlicky, Beloved Community. Critical Dogmatics After Christendom (Grand Rapids, Mich.: Eerdmans, 2015), 84-93.

49. See Bauckham, God, 1-22.

50. Fatehi, Relation, 303, italics mine, himself citing Lloyd Neve, The Spirit of God in the Old Testament (Tokyo: Seibunsha, 1972).

51. Samuel Terrien, The Elusive Presence: Toward a New Biblical Theology (San Francisco: Harper \& Row, 1978).

52. Sven Petry, Die Entgrenzung JHWHs: Monolatrie, Bilderverbot und Monotheismus im Deuteronomium, in Deuterojesaja und im Ezechielbuch (Tübingen: Mohr Siebeck, 2007).

53. By "relational" I do not necessarily mean more than "[t]he way in which one person or thing is related to another" (Judy Pearsall and William R. Trumble, eds, The Oxford English Reference Dictionary [Oxford: Oxford University Press, 1995], 1216). Depending on context, this could imply some kind of interpersonal relationship. Although Holmes may be correct that the fudging around this term on precisely this matter has created problems in modern theology, as I deploy it this will not be an issue (Holmes, "Classical," 28, 37-39). 
of neutral discourse, but rather one to whom Israel was (or at least was meant to be) completely devoted. This comes to particularly poignant expression in the Shema (which I take to mean at least Deut. 6:4-9, not just 6:4), and its reception. ${ }^{54}$ Waaler's study of the reuse of the Shema and the First Commandment in first century culture rightly claims that "to know that 'God is the only God' or that 'he is one' implies that one relates to one God only".55 MacDonald's important study of the Shema in Deuteronomy argues that its confession is not about the non-existence of other gods. Rather, it emphasises the personal and relational in terms of the confession that YHWH is one. Monotheism, for MacDonald, is not simply "a truth to be comprehended". In Deuteronomy, it is "a relationship in which to be committed". ${ }^{56}$ This seems consistent across second temple literature. Hence, the major Old Testament theologies arrange their material according to relational categories. ${ }^{57}$

(3) The third thesis follows from all of this: the God-relation pattern is unique to God alone across the texts of second temple Judaism, and in this way the "transcendent uniqueness" of God was expressed and conceptualised. Against those who speak of Jewish monotheism as either nonexistent, anachronistic, as "inclusive" (not "exclusive"), ${ }^{58}$ and so on, Bauckham rightly speaks of the "uniqueness of YHWH that puts him in a class of his own", such that the one God of Israel was conceived, by Paul's Judaism, to be "transcendently unique". ${ }^{59}$ However, this becomes clear only when the broader relational pattern is kept in mind, one evidenced to a usually greater than lesser extent across the texts of second temple Judaism that speak of God. There is another common mistake here, so let me be clear. This transcendent uniqueness of God was not based on monolatry, the exclusive worship (cultic or otherwise) of God alone. Worship was indeed part of the expression of that uniqueness, but the matter cannot be reduced to this. After all, the prophets would scorn such cultic worship (e.g., Isa. 58:1-14; Amos 5:21-27; Zech. 7-8) if it did not reach into the whole of life, as the Shema makes clear (see Deut. 6:4-9). ${ }^{60}$ The transcendent uniqueness of God is seen in the Godrelation language, which is only ever used with reference to the one God and not, in any second Temple texts, in terms of any intermediary figures, however exalted. ${ }^{61}$

54. I still find it difficult to believe that Ehrman does not reference the Shema once in Bart D. Ehrman, How Jesus Became God: The Exaltation of a Jewish Preacher from Galilee (New York: HarperCollins, 2014).

55. Erik Waaler, The Shema and the First Commandment in First Corinthians: An Intertextual Approach to Paul's Re-Reading of Deuteronomy (Tübingen: Mohr Siebeck, 2008), 202, italics mine.

56. Nathan MacDonald, Deuteronomy and the Meaning of "Monotheism" (Tübingen: Mohr Siebeck, 2003), 97.

57. Most obviously, one could mention Walter Eichrodt's two volume Theology of the Old Testament (Walther Eichrodt, Theology of the Old Testament. Vol. 1, trans. J. A. Baker [Philadelphia: Westminster John Knox, 1961]; Walther Eichrodt, Theology of the Old Testament. Vol. 2, trans. J. A. Baker [Philadelphia: Westminster John Knox, 1967]), but in truth, these themes are in most comparable treatments.

58. I am referring to scholars such as William Horbury, Margaret Barker, and Peter Hayman. See Tilling, Paul's Divine Christology, 17-19, for discussion and references.

59. Richard J. Bauckham, "Biblical Theology and the Problems of Monotheism," in Out of Egypt: Biblical Theology and Biblical Interpretation, eds Craig Bartholomew, et al. (Milton Keynes: Paternoster, 2004), 210-11.

60. Tilling, Paul's Divine Christology, 60-61.

61. See Tilling, Paul's Divine Christology, 196-233, for a substantiation of this claim in relation to three texts which supposedly problematise the transcendent uniqueness of the one God. 
(4) These three theses, which clearly correspond to one another, also find expression together in Paul's language relating to God. Please note that in justifying this fourth thesis, I do not intend the following references to be exhaustive, but only illustrative. ${ }^{62}$

- Communication. We read that God speaks (2 Cor. 4:6; 6:1), and humans pray to God (Rom. 1:9-10; 10:1; 15:30; 2 Cor. 11:13; 13:7; Phil 1:3-4; 1 Thess. 3:10-13).

- Presence and activity. God is active (Rom. 4:17; 8:9; 9:16; 11:23; 13:1-2; 1 Cor. 1:29; 2:12) in Paul's mission (Rom. 14:20; 1 Cor. 2:4; 3:6; 2 Cor. 2:17; 3:4-6; 4:7; 6:7; 12:19; 13:4; 1 Thess. 3:11-13), in the church (1 Cor. 3:16; 7:24; 12:18, 24, 28; 14:25; 2 Cor. 6:16; 9:8, 14; Gal. 3:5; Phil. 1:6; 2:13; 4:19), in the church's worldly situations (1 Cor. 10:13), and in individuals (Rom. 9:16-18; 2 Cor. 8:16).

- Spirit. This presence and activity is spoken of also in terms of the Spirit (Rom. 5:5; 8:9; Gal. 3:5).

- "Absence". There is, however, a sense in which God is not fully present in the way he will be in the eschaton (1 Cor. 13:12; 15:28; 2 Cor. 4:18).

- Character. God is characterised in typical ways, as faithful (2 Cor. 1:18), loving (Rom. 5:5), wrathful (Rom. 5:9), gracious (Rom. 5:15), wise (Rom. 16:27), acting with forbearance and patience (Rom. 2:4), and so on.

- Devotion. It is expected that people serve, are slaves of and belong to God (Rom. 1:9; 6:22; 1 Cor. 3:9). They boast in God (Rom. 2:17; 5:11; 1 Thess. 1:9), know God (Rom. 1:19, 28; 1 Cor. 15:34; 2 Cor. 2:14; 10:6), love God (8:28; 1 Cor. 8:2), fear God (Rom. 3:18; 2 Cor. 7:1), hope in God (Rom. 4:18; 8:20), believe in God (Rom. 4:17, 20-22, 24; Gal. 3:6; 1 Thess. 1:8), believers have turned to God (1 Thess. 1:9); are 'alive to' God (Rom. 6:11; Gal. 2:19), live to please God (Rom. 8:8; Phil 4:18; 1 Thess. 2:4, 15; 4:1), present themselves to God (Rom. 6:13, 16; 12:1), praise God (Rom. 14:11), and are eschatologically accountability before God (Rom. 14:12) etc. Naturally, God is strongly associated with Paul's ultimate goals, motivations and aims: (Rom. 11:36; 2 Cor. 1:20; 5:13; Phil. 1:11; 2:11; 4:20). God-devotion language is contrasted in typical ways. The wicked do not know God (Rom. 1:21, 28), do not please God (Rom. 8:8), nor fear God (Rom. 3:18). They practise idolatry instead of turning to God (Rom. 1:25), and so on. This God-devotion language is, of course, expressed in a way that shows it was energetic and lively devotion. So Paul speaks of serving God in his spirit (Rom. 1:9), that tongues, which is a language spoken to God (1 Cor. 14:2, 28), is something Paul practises 'more than all of' the Corinthians (1 Cor. 14:18). Likewise, Paul regularly speaks of his constant, day and night praying to God (Phil. 1:4; 1 Thess. 1:2-3; 2:13; 3:10-13).

The above list corresponds, of course, to our first thesis. It also reflects a Pauline redoublement of the second thesis. Dunn notes that Paul's speech about God was "Jewish through and through", ${ }^{63}$ which means here that it is a relationally accented faith in God. This is not to deny that "God" is decisively reshaped and

62. More exhaustive references can be found in Tilling, Paul's Divine Christology, 236-39. I have also lifted, and lightly adjusted, some of the following from those pages.

63. Dunn, Theology, 29. 
rethought around Jesus and the Spirit. ${ }^{64}$ Nor is it to deny that Paul's hermeneutic effectively amounts to an apocalyptic or retrospective reshaping. But certain themes, and the shape of the whole, bears family resemblance to what we find in Paul. Dunn writes the following about knowledge of God in Paul:

It is not merely a theoretical acknowledgement that theism is a viable intellectual position. To know God is to worship him ... to know God is to be known by him, a two-way relationship of acknowledgment and obligation (Gal. 4.9). As in the (Jewish) scriptures, the "knowledge of God" includes experience of God's dealings, the two-way knowing of personal relationship. ${ }^{65}$

So in 1 Corinthians 8, containing a key text in the hands of Hill for explicating the relationship between the Father and Jesus, Paul frames the whole in terms of this relational "monotheism". As Wright summarises:

Paul responds to the claim to $\gamma \nu \tilde{\omega} \sigma \iota \varsigma$ by insisting on the primacy of (not love in general, but) the Jewishstyle allegiance to the one God ... The real Gnosis, Paul is saying, is not your Gnosis of God but God's Gnosis of you, and the sign of that being present is that one keeps the Shema: you shall love the Lord your God with all your heart. ${ }^{66}$

Further, this is placed in a context which sets this relational commitment over against idolatry (1 Cor. 8:45). Similarly, in 1 Thessalonians 1:9, Paul writes of how the Thessalonian Christians "turned to God from idols, to serve a living and true God". The rejection of idolatry was here not merely the intellectual conception that idols did not exist, but involved the life of the new believer, with "turning" expressed in "serving". One could also refer to 2 Corinthians 6:16 and Galatians 4:8-9, among other passages, to make the same point, but I have done this elsewhere. ${ }^{67}$ Paul's knowledge of God was expressed and therefore conceived in relational terms. To know God was to be in relationship with God. But it follows from this that God's "transcendent uniqueness" for Paul was likewise so expressed and conceptualised. It was not understood simply as the abstract denial of other gods. The denial took shape in an exclusive commitment to the one God over against all forms of idolatry and evil, and so this God-relation pattern is what conceptualised God as "transcendently unique".

(5) In light of all of this, the thesis I propose and defend in Paul's Divine Christology seems natural: In dozens and dozens of passages across his letters, ${ }^{68}$ Paul uses language about Christ which shows precisely the same shape as that used to speak of (exclusive) faith in God, as noted above. For Paul, the Christrelation can be portrayed as follows.

- Communication. Christ is prayed to and Christ speaks back (Rom. 10:9-13; 1 Cor. 16:22; 2 Cor. 10:18; 12:8-9; 13:3; 1 Thess. 3:11-13).

64. To use language unnervingly like that regularly deployed by N.T. Wright, especially in N.T. Wright, Paul: Fresh Perspectives (London: SPCK, 2005) and N.T. Wright, Paul and the Faithfulness of God (Minneapolis: Fortress Press, 2013). 65. Dunn, Theology, 47.

66. N.T. Wright, The Climax of the Covenant: Christ and the Law in Pauline Theology (Edinburgh: T\&T Clark, 1991$), 127$.

67. Tilling, Paul's Divine Christology, 70.

68. I will refer in the following only to some. 
- Presence and activity. Christ is present and active in various ways (Rom. 1:7; 8:9-10; 14:4; 15:18-19, 29; 16:20; 1 Cor. 1:3; 3:5; 4:19; 7:17, 25; 16:17, 23; 2 Cor. 1:2; 2:10, 12; 3:3; 12:7-10; 13:3-5, 13; Gal. 2:20; 4:6; 6:18; Phil. 1:2, 19; 3:21; 1 Thess. 3:11-13; 5:28; Philem. 3, 25).

- "Absence". Christ is at the same time also strangely "absent" (1 Cor. 11:26; 15:23; 2 Cor. 5:6-8; Phil. 1:20-24; 1 Thess. 2:19; 3:13; 4:17; 5:10, 23).

- Spirit. So Christ is present and active by the Spirit (Rom. 8:9-10; 15:18-19; Gal. 4:6; Phil. 1:19).

- Character. Christ is characterised in ways that overlap considerably with his own, and other, Jewish God-talk (Rom. 8:35; 10:12; 14:4, 9; 11:27-30; 15:45; 2 Cor. 4:13; 5:14; 10:1; 13:5; Gal. 1:1, 11-12; 2:20; Phil. 1:8; 3:21; 1 Thess. 4:6).

- Devotion. Paul expresses devotion to Christ—which includes so-called "cultic worship", but also goes well beyond it - in striking, lively and consistent ways. Just as in Jewish God-language, this devotion is contrasted with certain themes such as sin, idolatry and the like (Rom. 1:5; 12:11; 14:69; 16:5; 1 Cor. 1:7 [cf. also Phil. 3:20]; 1:31; 2:2; 6:13, 16-17; 7:25-38; 8:12; 10:9, 20-22; 11:23-26, 3032; 12:3; 15:19, 58; 16:18, 22; 2 Cor. 3:16-18; 4:4-5; 5:9-10, 15; 8:5, 19; 10:7; 10:17; 11:2-3; 12:7-10; Gal. 1:10; 2:20; 3:29; Phil. 1:20, 23; 2:6-11, 21; 3:1, 8; 1 Thess. 1:2-3; 3:8; 4:17; 5:10; Phile 6).

This pattern of data found across all of Paul's letters is what I call the Christ-relation. It is a pattern that I argue Paul would also have recognised as such (i.e., as a pattern) as it constitutes, to a rather greater than lesser extent, an existential reality in Paul's life. These themes are not merely a collection of loose, unrelated ideas. They are also regularly found together in single arguments in Paul's letters. So the fifth thesis is obvious: the Christ-relation, and only the Christ-relation, has the same shape, same major themes and basic content as expressed in Jewish God-language, Paul's included. ${ }^{69}$

(6) This corresponds with Paul's "way of knowing". The sixth thesis: for Paul, (theological) knowledge can be expressed as relationship. Just as faith in God was expressed and understood in relational terms for second temple Judaism and for Paul within that milieu (theses two and three above), it is a natural step to recognise that Paul's way of knowing theology and Christology, his theological epistemology, was likewise relational. Indeed, Dunn claims that "whereas in Greek thought the term ["to know"] characteristically denotes a rational perception, the Hebrew concept also embraced the knowing of personal relationship". ${ }^{70}$ Dunn considers Paul to be an example of this "Hebrew" approach. More important is the precise study of Ian

69. Bearing in mind Alan Torrance's objection that Moltmann's understanding of worship is "rather Pelagian" (Alan J. Torrance, Persons in Communion: An Essay on Trinitarian Description and Human Participation, with Special Reference to Volume One of Karl Barth's Church Dogmatics [Edinburgh: T\&T Clark, 1996], 310-11), I do not mean to repeat the same mistake by implying that Paul's Christ-relation is likewise some kind of Pelagian basis for theology, as if it all depends on humans and the purity of their devotion. For Paul, relation to God and Christ is and remains a gift of sheer grace, one made possible only because of Christ's faithfulness to death and eternal life at the right hand of the Father (see, e.g., Rom. 6:4-5; 8:29-39; 15:17-18; Phil. 2:13).

70. Dunn, Theology, 46. A crude distinction between 'Greek' and 'Hebrew' should be challenged (Ian W. Scott, Implicit Epistemology in the Letters of Paul: Story, Experience and the Spirit [Tübingen: Mohr Siebeck, 2006], 146-47), but exaggerations aside, there is salvageable truth in Dunn's claim. 
Scott, as well as the collection of essays in the Healy and Parry edited volume. ${ }^{71}$ So Scott submits that knowledge of God, for Paul, involves "a harmonious relationship with the Creator". ${ }^{72}$ Mary Healy gets to the nub most profoundly when she argues that, for Paul, knowledge is expressed as relationship. ${ }^{73}$

Take 1 Corinthians 8 as an example again. Responding to the knowledge of the Corinthian "knowledgeable", Paul talks epistemology. They say "all of us possess knowledge" (8:1), so Paul responds by counterclaiming "knowledge puffs up, but love builds up". This is not to say that Paul was a crass antiintellectual, as some have misread him at this point. No, for Paul goes on in the next verse to speak of a

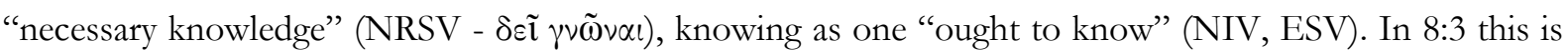
further elucidated. That necessary knowing involves loving God and being "known by him". This strange formulation ("to know" as a passive perfect with God as subject) is likely to be understood in terms of the Hebrew word ידע (often glossed as "to know"). Schnabel explains: "' with God as subject means 'to attend to a person' and describes the special relationship between Jahwe and Israel or individual Israelites". ${ }^{74}$ To speak of God's knowledge of humans is to speak of God's special relationship with his chosen people (see Amos 3:2, for example). Waaler therefore rightly concludes his study of $8: 3$ by maintaining that "to love God and to be known by God (1Cor 8:3) describes the personal relationship between the believer and God", 75 themes clearly echoed, of course, also in 8:6 where Paul draws on the language of the Shema to pursue his argument. It follows from all this that Paul's Christ-relation is a form of knowing. The Christ-relation is Christology.

(7) My seventh thesis is more combative. Many argue that divine agency figures are the key for understanding Christ in Paul's letters. Indeed, there is some obvious plausibility to this. Christ, Paul says, is at the right hand of God (Rom. 8:34). The Father is also "the God" of Jesus Christ (Rom. 15:6). And Christ can be spoken of with language you find associated with various exalted intermediary figures in Jewish literature around the time of Paul. They can bear the divine name, have passages from the Jewish Scriptures which speak about God applied to them, and they can even receive worship. So many will prefer this as the least anachronistic hermeneutic for grasping the significance of Christ, for Paul. However, when Paul's Christ-relation language as a whole is kept in mind, it becomes obvious that agency figures are less than helpful for understanding Paul's Christology. None of these intermediary figures, however exalted, are described in comparable fashion. None can be mapped on to the God-relation pattern. Indeed, even in those texts which say the grandest things about intermediary figures, it is the way God is spoken of even in those texts that corresponds best with Paul's Christ-relation. I offer a thought-experiment in Paul's Divine Christology at this point. Imagine Paul only had those texts (such as the Similitudes of Enoch and the Life of

71. Scott, Epistemology; Robin Parry and Mary Healy, eds, The Bible and Epistemology: Biblical Soundings on the Knowledge of God (Milton Keynes: Paternoster, 2007).

72. Scott, Epistemology, 150, italics mine.

73. Cf. the section title in Mary Healy, "Knowledge of the Mystery: A Study of Pauline Epistemology," in The Bible and Epistemology, eds Mary Healy, Robin Parry (Milton Keynes: Paternoster, 2007), 142, as well as 145-56.

74. Eckhard J. Schnabel, Der erste Brief des Paulus an die Korinther (Wuppertal: R. Brockhaus Verlag, 2006), 442-43, translation mine.

75. Waaler, Shema, 351. 
Adam and Eve) in front of him when developing his understanding of the significance of Christ. It would not be the exalted figures in these texts, such as Enoch's "Son of Man", but only the God-relation in these texts that would correspond with Paul's Christ. In other words, and this is my seventh thesis: Paul's Christrelation, seen in terms of all second temple literature, corresponds only with the Jewish God-relation.

(8) My eighth and penultimate thesis makes a claim about Paul's Christology. It comes as something of a climax of the rest and presupposes them. Paul's Christ-relation is Paul's divine Christology understood in precisely the way the "transcendent uniqueness" of the one God was expressed. It is the very Jewrish way Paul speaks of Christ as "on the divine side of the line". It is Paul's Athanasianism, ${ }^{76}$ the kind of exegesis that corresponds with the later creedal language of "bomoousios with the Father". As noted above, Hill claimed that "God and Jesus are identified with one another at the level of the shared divine name". My exegesis suggests that this formulation is not incorrect, just inadequate.

(9) But notice the crucial proto-Trinitarian point which constitutes the ninth thesis: Both the God-and Christ-relations are actualised, made a relational reality by the Spirit, and only the Spirit. Just as the Spirit is "God's activity as he relates himself to his world, his creation, his people" (Fatehi), so too is the Spirit the one who mediates the presence of the risen Lord. ${ }^{77}$ This is why people in, say, Paul's Corinth could pray to Jesus and expect him to answer and order their lives. It is why Paul believed, according to 1 Thessalonians 3:12-13, that his prayers would mean that the risen Lord Jesus, who died and rose again in Jerusalem, would strengthen the hearts of certain Christians in Thessalonica, which is approximately 1,500 kilometres away! What makes God's relationship with his people real, and what makes Paul's Christology possible, is the Holy Spirit.

To recap the nine theses:

(1) In second temple Judaism, God-language was expressed in terms of a broadly consistent and identifiable pattern (God was present and active, devoted to, characterised in typical ways, communicated with, and so on)

(2) This Jewish faith in God was also understood in relational terms. It was never simply "a truth to be comprehended", but "a relationship in which to be committed".

(3) The God-relation pattern is unique to God alone across the texts of second temple Judaism, and in this way the "transcendent uniqueness" of God was expressed and conceptualised

(4) These three theses find expression together in Paul's language relating to God. I.e., we find this "transcendently unique" God-language pattern understood in relational terms.

(5) The Christ-relation, and only the Christ-relation, has the same shape, same major themes and basic content as expressed in the Jewish God-language pattern, Paul's included.

(6) For Paul, (theological) knowledge can be expressed as relationship. Paul's Christ-relation is a form of knowing. The Christ-relation is a Christology.

\footnotetext{
76. Tilling, "Campbell's Apocalyptic Gospel and Pauline Athanasianism."

77. On this, see also the work of my own Doktorvater, Max Turner, “Trinitarian' Pneumatology in the New Testament?

- Towards an Explanation of the Worship of Jesus," AsTJ 58, no. 1 (2003): 167-86.
} 
(7) Paul's Christ-relation, seen in terms of all second temple literature, corresponds only with the Jewish God-relation.

(8) Paul's Christ-relation is Paul's divine Christology understood in precisely the way the "transcendent uniqueness" of the one God was expressed. It is the very Jewish way Paul speaks of Christ as "on the divine side of the line".

(9) Both the God- and Christ-relations are actualised, made a relational reality by the Spirit, and only the Spirit.

Armed with these theses, I finish by drawing out some implications for discussions relating to Paul and the Trinity, in dialogue with Hill. Due to space, I will limit myself to four points.

First, it needs to be stated that Hill is correct to draw attention to those passages in Paul which speak of the relations between Father, Son and Spirit as mutually identifying. Despite disagreements relating to exegetical details, the nine theses above suggests that Hill's procedure is basically correct. He has successfully illuminated the dynamic by which the three divine agents, in Paul, mutually constitute the divine identity. We also argue that the God- and Christ- relations are what they are because of the Spirit. We noted, too, that Paul's divine Christology is seen as such precisely by stressing the "transcendent uniqueness" of God in terms of a relational pattern. It is in these terms that the unity of the three agents is understood. The Father and Jesus are the only two subjects of the exclusively unique relation-pattern. The Spirit, for Paul, is likewise the unique and exclusive mediator of the personal presence of Father and the Son in this relationality.

Hill is quite correct to insist that care is needed here. For Paul, this isn't simply to say that Jesus is to be measured against some kind of pre-christological "monotheism". God, for Paul, is and always was "God the Father of the Lord Jesus". However, it is equally wrong to suggest that Paul's God-language can be understood in isolation from Jewish monotheistic concerns. Interpreting Paul involves a good grasp of the dynamics of Jewish monotheism, even when these concerns are reshaped or given different emphasis by Paul in light of Christ. Jewish monotheism remains a crucial element in Paul's cultural "encyclopaedia". ${ }^{78}$ This is to suggest that, in practice, Hill's application of a Trinitarian hermeneutic was a little too one-sided. The interrelation of themes and concepts with Paul's letters took a backstage. When greater emphasis is placed on exegeting Paul himself as well as his own historical particularity, a number of further points can be developed.

To wit, and second, what emerges is the centrality of the epistemic conditions of Paul's protoTrinitarianism. Recognising this leads to a greater appreciation for the mutuality between Paul and "the

\footnotetext{
78. The use of the word "encyclopaedia" in this context is informed by Umberto Eco. As Desogus remarks in his helpful essay: "the encyclopedia [in Eco's novel, The Name of the Rose] is akin to an immense library whose books accrue knowledge as it has been represented by cultures of different epochs. However, the library must not simply be considered an archive. The library is also a space wherein books talk with each other, generate intertextual links, and display possibilities of meaning that can be used in order to produce new signs" (Paolo Desogus, "The Encyclopedia in Umberto Eco's Semiotics," Semiotica. Journal of the International Association for Semiotic Studies 192, no. 1/4 [2012]: 501-2). See the suggestive comments also in Douglas A. Campbell, The Deliverance of God: An Apocalyptic Rereading of Justification in Paul (Grand Rapids, Mich.: Eerdmans, 2009), 990.
} 
spirit of early Christian thought", as Robert Wilken would call it (particularly on the matter of the Trinity). We noted Gregory of Nazianzus and Augustine above, but many more could be brought into this discussion. Origen, "arguably the greatest and most influential theologian of the third century, whose teaching cast a large shadow on the trinitarian controversies of the fourth century", ${ }^{79}$ contributed his best theology when operating within the same epistemic conditions. "To know", for Origen, meant to "participate in something" or be "joined to something", says Wilken. ${ }^{80}$ Gregory the Great said that there "can be no knowledge of God without a relation between the knower and God". ${ }^{11}$ Of course, one should also note that creedal language is framed in terms of " $\mathrm{I} / \mathrm{We}$ believe". So Lash writes that the "threefold confession in the [Apostle's] Creed declares our present relationship with God". ${ }^{82}$

Precisely this aspect, it seems to me, is something Paul Fiddes has made uniquely central to his own articulation of Trinitarian doctrine in his illuminatingly titled monograph, Participating in God. ${ }^{83}$ His discussions relating to Trinitarian dogma claims that it is not "the language of a spectator, but the language of a participant". ${ }^{84}$ As we shall see in the next section, this informs Fiddes' ontological decisions.

Third, when things are framed as above with my nine theses, it becomes clear why a Trinitarian hermeneutic is a resource rather than a liability, ${ }^{85}$ why, that is, Christ's distinction from the Father, in Paul's language, isn't better understood simply in terms of the divine agency of intermediary figures, exalted angels, Enoch's "Son of Man", and such like. The nine theses facilitate more sufficiently the theological task of assessing the appropriateness of a Trinitarian reading of Paul's language.

Fourth, by taking the historical particularity of Paul more seriously, we are better positioned to engage in more constructive discussion with Trinitarian theology. Rather than simply noting that the category of "relation" is important for both classical theism and 20th century, post-Barth, developments, Paul will indeed offer an adjudicating voice in contemporary debates. For just as Holmes notes, the development of the doctrine of the Trinity is "largely a lengthy exegetical debate". ${ }^{86}$ This suggests a procedure. Fiddes rightly notes that, in speaking of the Trinity, we should "give primary written authority in making Christian doctrine to the Holy Scriptures". 87

Indeed. So we turn, in our final section, to draw out the implications of this portrayal of Paul and the Trinity for a particular contemporary debate. I will proceed, all the while bearing in mind the work of Fiddes, by engaging the work of Holmes.

79. Khaled Anatolios, Retrieving Nicaea: The Development and Meaning of Trinitarian Doctrine, foreword by Brian E. Daley (Grand Rapids, Mich.: Baker Academic, 2011), 16.

80. Robert Louis Wilken, The Spirit of Early Christian Thought: Seeking the Face of God (London: Yale University Press, 2003), 21. See also 12.

81. Cited in Wilken, Early Christian, 21.

82. Nicholas Lash, Believing Three Ways in One God: A Reading of the Apostles' Creed (London: Notre Dame Press, 1993), 30, italics his.

83. Paul S. Fiddes, Participating in God: A Pastoral Doctrine of the Trinity (London: Darton, Longman and Todd Ltd, 2000). 84. Ibid., 37.

85. Cf. Hill, Paul and the Trinity, 31.

86. Holmes, The Holy Trinity, 54.

87. Paul S. Fiddes, "Relational Trinity: Radical Perspective," in Two Views on the Doctrine of the Trinity, ed. Jason S. Sexton (Grand Rapids, Mich.: Zondervan, 2014), 162. 


\section{THE APOSTLE PAUL IN DIALOGUE WITH RECENT TRINITARIAN DEBATES}

Due to space limitations, my comments must now be more cursory and suggestive, rather than fully developed. And I am very conscious that I remain a humble Neutestamentler speaking into a highly specialised systematic theological domain. ${ }^{88}$ With this in mind, it is not my concern to speak directly into the proposals developed by Fiddes. I do that tangentially. Instead, I will critically reflect on claims made by Holmes in three recent, important and learned publications. ${ }^{89}$ Please also note that the following points are in a sense cumulative, rather than self-contained.

1. Worship. Holmes presents the popular theory that the emergence of Trinitarian dogma proceeded from the basis of monotheism, on the one hand, and the "New Testament worship" of Jesus Christ on the other. ${ }^{90}$ But as I have stressed above, "worship" simply is not the defining feature of New Testament Christology, and it is high time that this misleading claim was given a decent burial. It is part of the matter, for sure, but only part. I suspect this judgment also informs Holmes' view of the Trinity as “necessarily and precisely useless" (out of a legitimate desire not to instrumentalise God's perfection), because he ties this directly to the human end to "glorify God". ${ }^{91}$ However, as we have seen, for Paul and for the fathers, the knowledge of the Trinity involves lives of service and love. Worship is a part of that wider lived reality but not its sum total. Trinitarian faith is "a form of knowledge that comes by faith and service to God" (Gregory of Nazianzus). On this issue at least, it seems to me that Fiddes manages to hold the breadth of Christian participation in view, when speaking of the Trinity. ${ }^{92}$

2. Scripture. I must also register my concern that debates relating to the Trinity are moving not towards, but away from Scripture. A critique of Régnon's thesis, for example, is all well and good, and no doubt important. But although a correct reading of tradition is desirable, the tradition itself has always sought primarily to exegete Scripture. One need only read Augustine, or the Cappadocians, or Athanasius, or indeed any of the fathers, and one is confronted by page after page of Scripture citations, allusions and exegesis. Simply put, I do not see the same in Holmes (even though it is to his credit that he has a chapter on "the Trinity in the Bible" in The Holy Trinity). If Holmes' task was simply to describe the tradition, then this may not seem overly problematic. But he does intend to contribute towards contemporary theological conversations, as is made clear by his insistence that modern expositions of the doctrine of the Trinity "misunderstand" and "distort" the traditional doctrine "so badly that it is unrecognizable". ${ }^{93}$ A profound

88. I.e., let me off lightly! Either way, it is surely best that we biblical scholars at least try to pursue these conversations, with humility, or biblical studies and systematic theology will unhappily continue to drift apart.

89. Holmes, The Holy Trinity; Holmes, "Classical"; Stephen R. Holmes, "Response: In Praise of Being Criticized," in The Holy Trinity Revisited: Essays in Response to Stephen R. Holmes, ed. Jason S. Sexton and Thomas A. Noble (Milton Keynes: Paternoster, 2015).

90. Holmes, “Classical," 31-34.

91. Ibid., 47.

92. Fiddes speaks of the Trinity in terms of a variety of life aspects in his pastoral account (Fiddes, Participating).

93. Holmes, The Holy Trinity, xv. 
question that seems to be given too short thrift is to what extent the work of somebody like Fiddes represents good exegetical insight.

As noted in the first section above, I remain unconvinced that relations of origin best express the work Hill has undertaken in terms of the apostle Paul. He wants to say more about relations, and rightly so. Biblical exegesis is indeed hardly a friend of Holmes' portrayal of relations at this point. When presented with (I think clear) evidence in the New Testament of distinctions between the Father, Son and Spirit that go beyond distinctions of origin (Gethsemane, Rom. 8:26 etc.), ${ }^{94}$ Holmes' responses effectively drive a wedge between the logos asarkos and the man Jesus of Nazareth. ${ }^{95}$ But this move raises its own set of theological dangers. In particular, it leads to sundering God's Word from the life of Jesus Christ, a problem the Barthian tradition has seen most keenly. ${ }^{96}$ This, in turn, creates a theological vacuum into which all manner of other "words" can gain access. Constructive theological proposals are more aware of the dangers involved here, it seems to me.

It is not, therefore, surprising to read the following revealing comment by Holmes in the response book to The Holy Trinity. He admits that "what we call 'the doctrine of the Trinity' is not a biblical idea, and is not defensible exegetically". ${ }^{97}$ Of course, he means that processions and such like are part of an interpretative construct and are not directly biblical. But either way, his rather shocking point hangs ominously in the air: the Trinity is "not a biblical idea". This kind of language is more than a little bit worrying, for the result is to effectively rend biblical studies and systematic theology apart precisely when open conversation is most necessary (as the fathers modelled for us). The danger is clearly that it might result in dislocating the Word of God from constructive theological work. ${ }^{98}$ If Holmes may respond to any of his critics with "the tradition says..." 99 I must insist that we be allowed to respond, "but Scripture says... and this tradition, in order to continue the tradition, needs to place itself continually under the judgment of God's Word". ${ }^{100}$ I realise that this claim involves a number of unspoken theological commitments, but space is limited so I cite Donald Wood who, in dialogue with Barth, writes: "The church is obedient to the Word of God in scripture alone; responsible to the church fathers and to the confessions; and neutral with regard to all other voices". ${ }^{101}$ If this is agreed in principle (is it?), then where is it in practice?

94. See Thomas H. McCall, "Relational Trinity: Creedal Perspective," in Two Views on the Doctrine of the Trinity, ed. Jason S. Sexton (Grand Rapids, Mich.: Zondervan, 2015), 117-27.

95. Stephen R. Holmes, "Response to Thomas H. McCall," in Two Views on the Doctrine of the Trinity, ed. Jason S. Sexton (Grand Rapids, Mich.: Zondervan, 2014), 142.

96. On all of this, reference must, of course, be made to Karl Barth, Church Dogmatics (Edinburgh: T\&T Clark, 196980), II/2. I am aware of the "Princeton debate" between McCormack and Hunsinger. I suspect that Hunsinger misrepresents McCormack on these issues in his most recent, slightly less than irenic volume (George Hunsinger, Reading Barth with Charity: A Hermeneutical Proposal [Grand Rapids, Mich.: Baker Academic, 2015]).

97. Holmes, "Response," 140.

98. By "Word" here, I do not mean simply "Scripture" (see Fiddes, "Relational," 162-63!). But neither can one drive a firm wedge between the Word and the words. At the very least to do so would constitute a firm break from tradition. 99. Please note how often the phrase "the tradition" is used in Holmes, The Holy Trinity. Nineteen on my count.

100. If this is not done, both the human aspect involved the task of dogmatics will be suppressed, and the sovereignty of God's Word will be compromised, which means God will cease to be God in theological discourse. On this, see now Christine Helmer, Theology and the End of Doctrine (Louisville: Westminster John Knox, 2014), 59-88.

101. Donald Wood, Barth's Theology of Interpretation, Barth Studies (Aldershot: Ashgate, 2007), 161. 
3. Paul and the "transcendent uniqueness" of God. In light of the previous exegetical section we can see that for Paul the divine unity is not simply about the word "oneness" understood in terms of essence. ${ }^{102}$ So what constitutes the unity of Father, Son and Spirit? The exegetical evidence suggests a relational dynamic, a transcendent uniqueness which is conceived not simply as an objective truth "out there" for humans to analyse "objectively". It is rather a pattern of life, love and commitment, a concrete and dynamic relational pattern which speaks of God and Christ as related to by the Spirit. Of course, much of this sounds like Fiddes (but see n. 103). Hence, humans are postured towards the "oneness" of God as disciples. Precisely because this is so, it is not something which these disciples possess. The element of truth in apophatic metaphysics, at least seen from a Pauline perspective, is the asymmetrical nature of relationship with God. It is a relationship initiated and maintained by God's grace alone, by the power of his Spirit (cf. 1 Cor. 2:910). ${ }^{103}$

So much for my exegetical proposal. My question is whether this would be seen as a distortion of traditional doctrine, in Holmes' view? Should I keep such exegesis to myself, in the knowledge that Aquinas supposedly had it all figured out?

Let me anticipate an objection. Am I seriously suggesting that biblical scholars have the right to march into discussions that have busied systematic theologians for centuries, and willy-nilly turn over tables based on a few Bible verses under the banner of "back to the Bible" or of semper reformandum? By no means, and certainly not willy-nilly! But it is to put questions to the tradition and ask what sort of theological conceptualities make reading Paul meaningful. As Holmes helpful explains:

'[T] he doctrine of the Trinity' is ... a set of conceptualities that finally allowed (or at least was believed to allow) every text to be read adequately. As such, it is not a 'biblical doctrine' in the sense of being the result of exegesis; rather, it is a set of things that need to be believed if we are able to do exegesis adequately as we hold to the truth of every text of Scripture. The doctrine of the Trinity is a conceptual framework that allows us to read every biblical text (concerning God's life) with due seriousness, but without discovering contradictions between them. ${ }^{104}$

So my question becomes: does a description of the unity of Father, Son and Spirit in terms of an abstract and apophatic "essence" help the Pauline exegete read his letters "with due seriousness"? Or is it not reductionist, perhaps even distorting matters? The question is an open one. If simplicity is taken to mean that to speak of God's oneness is to posit a different order of Being, one beyond our domestication, a "oneness" understood also in different orders of knowing, ${ }^{105}$ then this may indeed offer the Pauline exegete

102. Holmes knows this. I was impressed by his recourse to the important scholarship of MacDonald, Monotheism. 103. Cf. Fiddes who proffers an interesting, if ultimately unconvincing, suggestion that the apophasis is the notion of relations without subjects (Fiddes, Participating, 45; Fiddes, "Relational," 170-71). A better exegetical explanation understands the apophasis in different terms, as noted above.

104. Holmes, "Classical," 35.

105. Cf. Scott R. Swain, The God of the Gospel: Robert Jenson's Trinitarian Theology, Strategic Initiatives in Evangelical Theology (Downers Grove, Ill.: IVP, 2013), 157-58. 
(very vague) conceptual apparatus to read texts. But this is surely a minimalist understanding of the term. Holmes, I suggest, says more than this because of those proposals that he wants to exclude.

4. Ontology. We agree with Holmes when he speaks of the tradition's "ontological modesty". It may be that some relational approaches to the Trinity claim to know too much. ${ }^{106}$ So when Fiddes argues that identifying "the divine persons as relations brings together a way of understanding the nature of being (ontology) with a way of knowing (epistemology)", ${ }^{107}$ Holmes can respond by counter-asserting that Fiddes makes illegitimate argumentative jumps (leaps?). Indeed, we agree that Fiddes moves too fast in his argument at this point. More exegetical reflectiveness is necessary, at the very least, and with that in mind we shall meditate on these issues further below. A key goal is to construct second order proposals that make exegesis meaningful.

For Holmes, however, the point is made because of a commitment to the claim that the divine essence must remain unknowable, and therefore only distinctions of origin are "permissible". ${ }^{108}$ Precisely at this point a doctrine of simplicity finds its place as "a property of the divine essence". ${ }^{109} \mathrm{I}$ am left with three questions.

Before I start, I raise these questions tentatively as a mere Neutestamentler. Indeed, as an act of preemptive and prophylactic attrition, I must also state that I realise there are many different ways to understand simplicity, and I don't pretend to understand them all. For the Thomists, it is foundational in a particular sense (famously, Aquinas kicks off the Summa with analysis of "simplicity"). ${ }^{110}$ Barth also affirms it, though on a different basis. ${ }^{111} \mathrm{I}$ am also aware that there may be a number of philosophical advantages to the doctrine of simplicity. ${ }^{112}$ That said, there may be a number of potential philosophical disadvantages, too. ${ }^{113}$ These pro and contra arguments are, likewise, beyond me. I also realise that this is a heated area of debate into which I can only venture hesitatingly. I am particularly stung by Hart's bold claim that "denial of divine simplicity is tantamount to atheism".114 (Does not this suggest, in good Rahnerian fashion, that unless we assume all of the Apostles and Prophets were "Anonymous Simplicitarians", they must also have been atheists?). Hence, I largely reflect on simplicity as deployed by Holmes.

106. Holmes, "Classical," 36.

107. Fiddes, Participating, 38.

108. Holmes, The Holy Trinity, 200. As Roberto De La Noval kindly pointed out to me, for the fathers there may be things that make the Father, Spirit, and Son in se distinct in ways that are different from just sources of origination. But the point is that we cannot know that and are not to speculate on it. The point to make here, either way, is to ask to what extent specific understandings of divine mystery make biblical exegesis meaningful or not. In Scripture, distinctions other than one of origin seem obvious, as noted above. On different approaches to divine Geheimnisse, I found the comments in Barth, CD, II/2, p.146-51, rather helpful.

109. Holmes, "Classical," 39.

110. Gilles Emery OP, The Trinitarian Theology of Saint Thomas Aquinas, trans. Francesca Aran Murphy (Oxford: OUP, 2007), 38 n.9.

111. Barth, $C D, \mathrm{II} / 1, \mathrm{p} .440$.

112. Holmes notes a few (Holmes, "Classical," 38).

113. See, e.g., R. T. Mullins, "Simply Impossible: A Case Against Divine Simplicity," Journal of Reformed Theology 7 (2013): 181-203.

114. David Bentley Hart, The Experience of God (Yale: Yale University Press, 2013), 128. 
So, and first, why is Holmes' argument about ontological modesty and simplicity not self-refuting, for simplicity so understood is a (controlling) ontological claim? After all, Holmes repeats the point that simplicity is the basis for proper apophaticism, that it is "at the heart" of the shared doctrine of classical Trinitarianism, and is something "all agreed on". ${ }^{115}$ But Holmes likewise states that simplicity is an "ontological proposition". 116 So where has the ontological modesty gone?

My second question: as I do not want naively to claim we move directly from the exegesis of isolated Bible verses into ontology proper, is it not nevertheless correct to claim that ontological proposals need at the very least to make scriptural exegesis meaningful? We have urged above that the God-and Christrelations, actualised by the Spirit, constitute Paul's proto-Trinitarianism. My question is reflected in Schwöbel's recent comment: "If the homoousios is simply taken to mean that Father, Son and Spirit instantiate the same divine essence three times over, without rooting how God is in relation to the world in how God is in God's own being, one has effectively made the doctrine of the Trinity meaningless for understanding the divine economy." 117 My concern is that simplicity, in Holmes' hands, precipitates a reductionist Pauline exegesis.

Third, if simplicity is indeed controlling, whence this knowledge of God?118 On what basis is it claimed? In particular, How is this knowledge derived from the gospel? If it isn't, then what is the church doing courting it as foundational?

I can hear my imaginary interlocutors dismissing me as an unsophisticated "Barthian" already. Obviously I realise that Thomism is happy to court metaphysical speculation and natural theology. ${ }^{119} \mathrm{But}$ knowing this does not address my concern. Indeed, I pursue my question for a specific reason. Jenson begins his Systematic Theology by (uncontroversially) noting that " $[\mathrm{t}]$ heology is the church's enterprise of thought". But the fact of the matter is that the church is divided, and so it follows (unless one wants to claim that their confession is the one, true church) that "theology may be impossible in the situation of a divided church, its proper agent not being extant". ${ }^{120}$ Instead of a counsel of despair, Hinlicky reads this to mean that theologians need "greater clarity today about the epistemic access of the theological subject than has been the case". ${ }^{121}$ It is for precisely this reason that McCormack is correct to note this issue as an outstanding and "truly fundamental" difference between Barth and Aquinas. ${ }^{122}$ So I need to press my

115. Holmes, "Classical," 36, 39, 41.

116. Cf. Holmes, "Classical," 35.

117. Christoph Schwöbel, "Where Do We Stand in Trinitarian Theology?" in Recent Developments in Trinitarian Theology: An International Symposium, ed. Christophe Chalamet and Marc Vial (Minneapolis: Fortress Press, 2014), 23.

118. I have often heard my colleague, Lincoln Harvey, ask this question of theological proposals, and so I must credit him. See also Barth, $C D$, II/1, p.19.

119. On various misunderstandings of Barth relating to this language, see now Kevin Diller, Theology's Epistemological Dilemma: How Karl Barth and Alvin Plantinga Provide a Unified Response, foreword by Alvin Plantinga, Strategic Initiatives in Evangelical Theology (Downers Grove, Ill.: IVP Academic, 2014).

120. Jenson, Systematic Theology I, vii.

121. Hinlicky, Beloved Community, xviii.

122. Bruce L. McCormack, "Processions and Missions: A Point of Convergence Between Thomas Aquinas and Karl Barth," in Thomas Aquinas and Karl Barth. An Unofficial Catholic-Protestant Dialogue, ed. Bruce L. McCormack and Thomas Joseph White O.P. (Grand Rapids, Mich.: Eerdmans, 2013), 100. 
question. If one is committed to "essentialism" in the way Holmes appears to be, whence this knowledge of the divine? Is it not inevitable that natural theology and the analogia entis are now correlative commitments?123 But why would a Baptist theologian prefer these over the revelation of the free Word of God attested in Scripture, as the source of theological meditation on the Triune God? Surely Fiddes is, here at least, more consistent, ecclesially speaking.

5. Paul's proto-Trinitarianism. I submit, further, that this theological vision of the epistemological priority of God's free and personal self-donation is what we find in Paul. ${ }^{124}$ As Barth claimed: "the Bible always understands what it calls revelation as a concrete relation to concrete men". ${ }^{225}$ Diller summarises Barth's theological epistemology in ways that resonate profoundly with what I have said about Paul's protoTrinitarianism: "God makes himself personally known to us in relationship with us by the gift of communion with the Spirit, who is the subject of the knowing relation". ${ }^{26}$ This is emphatically not to suggest that philosophical speculation has no place in the theological task. Rather, they must always be "second-order reflections, derivative of an dependent on the actual knowing relation". ${ }^{27}$ Revelation is "fundamentally personal" and in this way it is "fundamentally rational". ${ }^{128}$ So my concern: if the theofoundation of the personal revelation of God in Jesus is itself determined by a second, external and regulative foundation (via natural theology), we are immediately distancing ourselves from Paul.

What is more, I doubt Paul's proto-Trinitarianism can be kept away from ontological reflection. My relevant exegetical results above can be summarised in the following twofold way, which I label $\chi 1^{*}$ and $\chi^{2 *}$

$\chi^{*}$ God and Jesus Christ, by the Spirit, are known in interpersonal and relational ways. This is to say that the graced, human epistemic access to Paul's proto-Trinitarian theology happens in terms of relationship with the Triune God.

$\chi^{*}$ Paul articulates a relational pattern which constitutes God's "transcendent uniqueness". The same constitutes his Christology as divine and, by the mediation of the Spirit, Paul's protoTrinitarianism.

For some who need to protect ontology from personalism or relationality understood in terms that go beyond distinctions of origin, one could dismiss the ontological implications of the exegetical arguments

123. Ibid., 126.

124. Attempts to lock Paul into "natural theology" via mention of Romans 1:20 are highly misleading. On this, see now Campbell, Deliverance, 469-600, 948-49.

125. Cited in Diller, Theology's Epistemological Dilemma, 51.

126. Diller, Theology's Epistemological Dilemma, 55.

127. Ibid., 86, italics mine.

128. Diller, Theology's Epistemological Dilemma, 54. This is to say that not all rational, philosophically informed speculation, should be rejected by those who seek to allow their epistemological source to be servant to the living Word. Speculation is arguably inevitable, but there are healthy and unhealthy varieties. See Barth's distinctions in Barth, $C D, \mathrm{II} / 2$, p.135 (a passage not noted by Diller). 
with the suggestion that Paul's letters evidence a relational epistemology, but not an ontology as such. ${ }^{129}$ And if $\chi 1^{*}$ was all we had to go on, this strategy of dividing ontology from epistemology may prove plausible. However, as we also have to do with $\chi^{2}$, which clearly corresponds with $\chi^{*}$ but goes beyond it, this distinction loses some appeal. The reason for this is simple. Left on its own, Paul's way of knowing could be captured or reframed in a very different ontological vision. But corresponding to $\chi^{1 *}$ Paul also articulates and therefore conceptualises God in relational form $\left(\chi 2^{*}\right)$, which means violence will be done to Paul's texts if we try to wrestle his language into alternative ontological structures, or rather dismiss proposals that emphasise relationality. In other words, $\chi^{1 *}$ and $\chi^{2 *}$ taken together are ontologically suggestive (even if we agree that we should not rush this argument, and that our ontology, informed by Paul, should remain modest).

What is the alternative to this conclusion? If $\chi 1^{*}$ and $\chi^{*}$ are to be distanced or even formally divided from theological ontology, then various problems are immediately evident. First, Scripture would then become formally separated from theological reflection at the level of ontology. Second, it would lead to the separation of the content of divine soteriological action, namely restored relationship with Christ and the Father by the Spirit, from theological reflection concerning ontology. These two points indeed insinuate a third problem, a greater tension between Holmes' ontological proposals and Paul's proto-Trinitarianism. Specifically, the Christ-relation and the Spirit's mediation of this relation, which Paul's Christology, understood in its historical particularity, is, must be taken as an analogy (or inadequate expression) of sometbing else, something more fundamental (an ontology which allows only relations of origin). But as noted, whence this knowledge? And if an ontology which suppresses all but relations of origin is embraced, what is to speak against apophatic agnosticism when it comes to biblical language, even when it is grounded in salvation in Christ?

\section{CONCLUSION}

After critically engaging the work of Hill, I suggested that the valuable task of bringing Paul and Trinitarian categories into conversation needed greater focus on historical questions and the breadth of Paul's language. In other words, we still need to speak more about Paul's trinitarianism. To do this, I presented nine theses, and the upshot was a greater focus on the epistemic conditions of Paul's language (which, we saw, resonates well with Patristic concerns, too). This facilitated a more robust conversation to take place with modern debates relating to the interpretation of the Trinity. I chose Holmes as my interlocutor, and raised questions largely from the perspective of my activity as a Pauline scholar. Throughout I noted points of grateful and critical contact with Fiddes' constructive theological project, particularly his understanding of the nature of participatory epistemology. I end by noting my concern as in some way an outsider to many of these

129. Rehfeld's interesting monograph has attempted to depict Paul's ontology in relational terms, though not in light of Paul's proto-Trinitarian rhetoric, which I find odd. See Emmanuel L. Rehfeld, Relationale Ontologie bei Paulus: die ontische Wirksamkeit der Christusbezogenheit im Denken des Heidenapostels, WUNT II (Tübingen: Mohr Siebeck, 2012). 
contemporary theological debates. I am an exegete, I work with the biblical texts in my academic work. Because of this, I worry that the present return of some to (hyper) Thomism ${ }^{130}$ has not only lead to an uncomfortably easy dismissal of all constructive theological endeavours that assume a potentially problematic reading of some (most?) Patristic sources, but that it is also in the process of isolating key aspects of theology from Scripture. As one who stands within a tradition which claims to be "Catholic and Reformed" (Anglicanism), my deep respect for classical theism and Thomas in particular is partnered by another instinct:

The Church stands in the fire of the criticism of its Lord ... It has always needed, and it always will need, self-examination and self-correction. It cannot exist except as ecclesia semper reformanda. ${ }^{131}$

130. McCormack, "Processions and Missions," 126. This arguably involves theology operating with less care about the proper epistemic sources for theology, something felt all the more keenly in the context of a divided church (Jenson). 131. Barth, CD, IV/1, p.690. My thanks to Roberto De La Noval, Lucy Peppiatt, Nikolai Kohler, Michael Leyden, and Andy Goodliff for critical comments on an earlier draft of this essay. 